\title{
Socio-economic determinants for adoption of riverbed farming in Deukhuri valley of Western Nepal
}

\author{
Shree Kumar MAHARJAN ${ }^{*}$ \\ ${ }^{1}$ Graduate School of International Development and Cooperation (IDEC), Hiroshima \\ University
}

\begin{abstract}
Riverbed farming $(\mathrm{RbF})$ has emerged as an alternative form of agriculture. This farming supports the poor and marginalized farmers to adapt to climate change, especially in the degraded lands because of floods and flood-induced riverbank erosions every year. The government and non-government organizations (GOs/NGOs) have supported and built capacities of farmers to adopt this as an effective adaptation strategy in the region. This study aims to analyze the determinants of riverbed farming at the household level mainly in the Deukhuri valley of the Western Terai, Nepal. A total of 150 households were selected randomly for the study in Sisahaniya rural municipality for the household survey. The determinants of the adoption of riverbed farming has been analyzed utilizing independent variables such as age, gender, education, occupation, ethnicity, family size and others. Education and occupation are positively significant for adoption of riverbed farming whereas the family size is negatively significant. Agriculture is the main occupation in the area. Education has helped them to understand the concept and procedures of $\mathrm{RbF}$ as alternative farming in the degraded lands. However, not all the family members have actively contributed to the RbF. This is interesting study that could be expanded with the support of GOs/NGOs.
\end{abstract}

Keywords: adaptation, agriculture, riverbed farming, Terai, Nepal

\section{Introduction}

Multiple adaptation strategies and practices have been adopted and promoted to address the impacts of climate change (Naz et al. 2018). However, one adaptation strategy may not be applicable to all affected sites. Thus, farmers need specific adaptation strategies and practices to deal with the specific impacts in the flood prone areas. Multiple risk management and adaptation practices/strategies adopted by the farmers themselves and with the support of public, private and civic institutions to address the specific and general issues and impacts of climate change. These strategies and practices are categorized as informal practices and formal 
strategies accordingly. The informal practices have included income and crop diversification, resource management at farm level whereas the formal strategies included the government policies/plans including the agricultural credit, crop insurance, information system etc. (Saqib et al. 2016). These strategies and practices may vary from region to region, area to area and farmer to farmer based on the specific exposure, sensitivity and adaptive capacities including the farmers' expertise, technical and financial capacity (Naz et al. 2018).

Riverbed farming $(\mathrm{RbF})$ is one of such practices/strategies in Terai region of Nepal, which is gaining popularity as an alternative form of agriculture in degraded and deteriorated land because of increased floods and flood-induced riverbank erosions in the region. This form of farming is the supportive and attractive among the poor and landless farmers in the region. It has huge potential in such degraded and waste lands in the region. It is considered as the alternative source of income and family nutrition, supporting the livelihood and food security (Maharjan 2017; Mor et al. 2018). Schiller et al. (2013) considered leasehold riverbed vegetable farming as the innovative farming technology especially for the livelihood and food security of the landless and marginalized farmers. They further emphasized on it as the economically, ecologically, socially and technically efficient form of agriculture for the marginal farmers. This form of agriculture uses the degraded and waste lands in the riverbanks for growing vegetables as the source of their livelihoods and income for the farmers (Mor et al. 2018). This form of farming is found across South Asia including India and Bangladesh. In fact, it is believed to be introduced in Nepal by immigrants from India (SATNET Asia, 4 October 2014).

Rivers have significant importance in people's livelihood, culture and welfare since the human history. "All the civilizations from ancient time in the world were grown on the bank[s] of rivers" (Mor et al. 2018, pp 3423). However, the settlements and agricultural lands in the riverbanks are highly sensitive with more exposure to the riverbank erosions in recent days due to proximity to the rivers. Many of ethnic nationalities, poor and marginalized people live in the riverbanks in Nepal. There is an estimation of 6000 rivers in Nepal including the rivulets and tributaries with the drainage density of $0.3 \mathrm{Km} / \mathrm{km}^{2}$ (WEPA, 2019). The people living in the riverbanks have comparatively less adaptive capacities to deal with the climatic shocks, stresses as well. Erratic and unpredictable heavy rain leading to floods and flood-induced riverbank erosions have changed the cultivable agricultural lands into uncultivable and degraded riverbeds in the Terai plains of Nepal. The significant mass of agricultural lands converted due to riverbank erosion, which has been increasing over years (Gurung et al. 2012). The RbF has emerged an option for the farmers and landless poor to maintain and support their 
livelihood by utilizing the available resources who have lost their agricultural lands from riverbank erosion due to floods and flood induced erosion. Thus, it is a climate-smart agricultural practice to adapt to climate impacts for rural, poor and landless households to generate income and sustain their livelihood (SATNET Asia, 4 October 2014). Mainly cucurbits are cultivated in the riverbeds (Gurung et al., 2012; Mor et al. 2018) since these crops can thrive even in the harsh climate and soil conditions (Maharjan, 2017), especially because of sand deposits in the banks due to floods and erosions (TECA N.D.). Furthermore, these crops can easily be harvested and sold in the local markets for family income.

It is important to understand the household responses to the riverbank erosion, including the factors that influence the response. There are merely few empirical studies done in riverbed farming in South Asia including Nepal though it has been promoted as the alternative source of agriculture, livelihood and food security in the region by the private and civic sectors especially by international and national non-governmental organizations (I/NGOs) including International Center of Integrated Mountain Development (ICIMOD), Helvetas Nepal, Mercy Corps, GIZ Nepal, Forum for Rural Welfare and Agricultural Reform for Development (FORWARD-Nepal), and riverbed farming alliance in Nepal (SATNET Asia, 4 October 2014). These organizations have motivated and supported the poor and landless farmers and households severely affected by the riverbank erosions in the region as supplementary livelihood options. The local riverbed farming promotion policy (2070 B.S.) was also finalized in 2013 (SATNET Asia, 4 October 2014). Some of the studies found in South Asia including India and Bangladesh are by Gurung et al. (2012); Alam et al. (2017); Naz et al. (2018); Mor et al. (2018); Alam et al. (2019) in recent years. This study aims to analyze the socio-economic determinants of households associated with the RbF in Deukhuri valley of Western Nepal.

\section{Methodology}

\subsection{Study Sites}

The study site is located in the Deukhuri valley of Dang district in Mid-western Nepal, borders to India in the south. It is one of the largest districts in Nepal situated in the Inner Terai. The total area coverage by the district is $2,955 \mathrm{Km}^{2}$ with the altitude ranges from 213 to 2058 meter above sea level with the tropical, subtropical and temperate climate. However, the study was concentrated in Sisahaniya Rural municipality. Agriculture is the main source of livelihood and economy in the district with $2 / 3$ rd of its population engaged directly on it. The major stakeholders supporting agriculture are government offices mainly agriculture, livestock and 
forestry offices, non-governmental organizations, agricultural banks, multipurpose cooperatives, local level community-based organizations, forest user groups, farmers' groups etc. The support of non-governmental organizations and cooperatives are importation in the $\mathrm{RbF}$. Rapti and Babai are two major rivers with many small streams and tributaries for the water resources and irrigation, which also destroy the agricultural lands through riverbank erosions particularly because of heavy and erratic rains in monsoon every year (DDC-Dang 2071 V.S.).

Based on the overall vulnerability index (VI) stated by the Ministry of Environment, DangDeukhuri is considered as the low vulnerable district (MoE 2010). However, the vulnerabilities, risks, impacts and adaptation interventions vary even within the district due to the variations in altitude and climate including the difference in sensitivity, exposure and adaptive capacities of the localities and communities living in the areas. Dang-Deukhuri, itself, has tropical, subtropical and temperate climates within the district based on the elevation and the vulnerabilities, risks, impacts and adaptation interventions as well. The Figure 1 presents the administrative and climatic variations, particularly due to flood within Dang-Deukhuri district. The study sites are under the high (more than 4 times) and moderate (2-3 times) flooded in the years between 2006 to 2014 (UN-NIP 2017). As per the district and VDC profiles, Deukhuri valley faces the issues of flood, riverbank erosion, drought, forest exploitation, reduced agricultural production and emergence of new insects, diseases and pests, drying of the water sources (Sisahaniya VDC 2073 V.S.). 


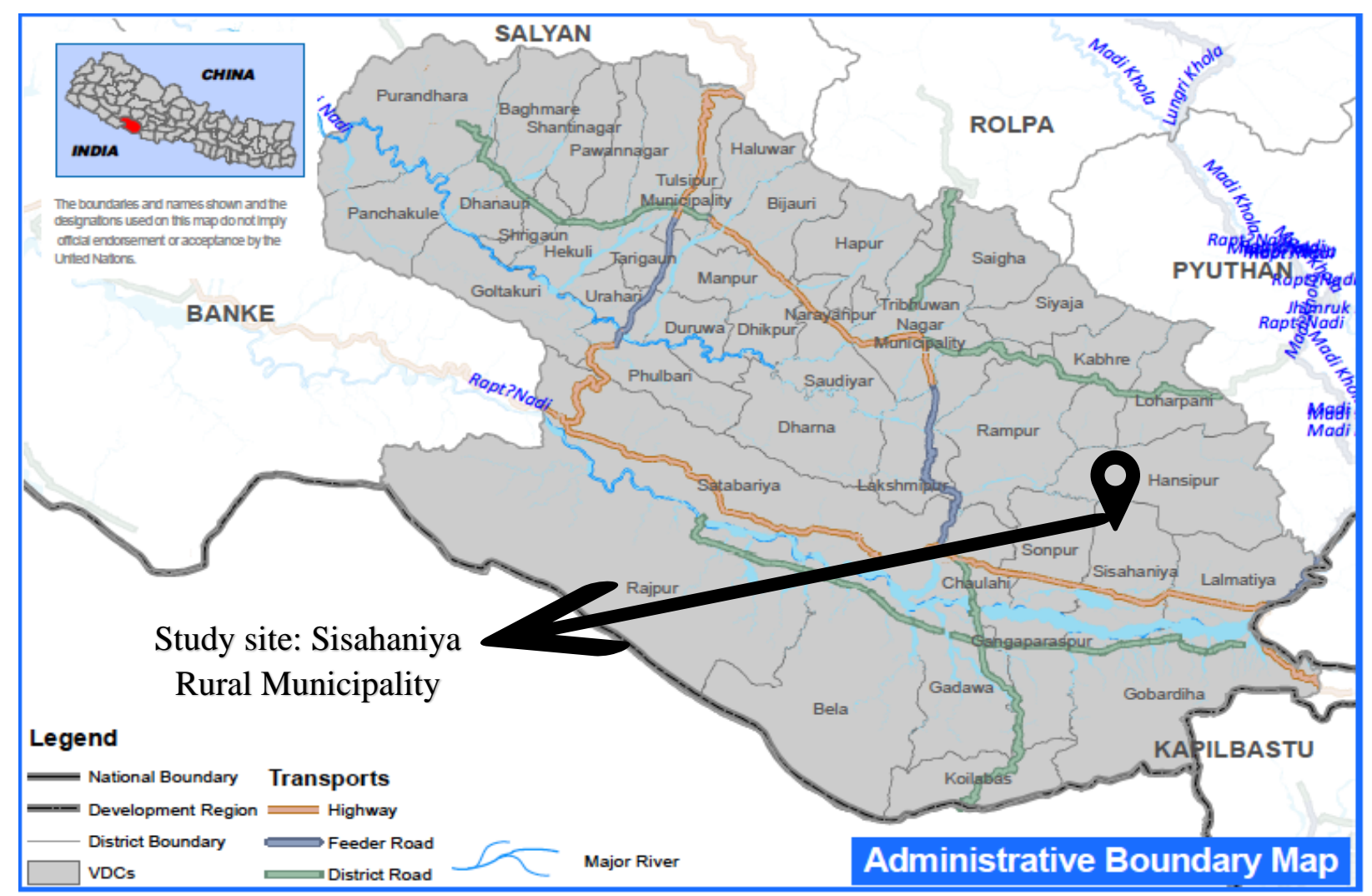

Figure 1: Map of Deukhuri-Dang district with administrative boundaries

Source: UN-NIP 2017(http://www.un.org.np)

\subsection{Empirical model and selection of the variables}

Many researches have shown that farm households have been attempting to deal with the climatic hazards including riverbank erosion through multiple adaptation strategies including riverbed farming (Alam et al. 2019). Naz et al. (2018) emphasized on the analysis of determinants that influence the adaptation strategies and practices at the household level to address the impacts of floods and other climate impacts. Mittal and Maher (2015) used Multivariate Probit Model (MVP) to analyze the determinants of farmers adopted in agriculture. Sebopetji and Belete (2009) used binary probit model to analyze the factors affecting smallholder's decision to take credit, which is application in this study as well. This model estimates the probabilities dependent variable between 0 for not adopting riverbed farming and 1 for adopting riverbed farming among the selected samples. The details of independent variables are presented in the Table 1.

The equation of the regression model is assumed to be:

$$
Y_{i}^{*}=\beta_{0}+\beta_{1} x_{1 i}+\beta_{2} x_{2 i}+\cdots+\beta_{k} x_{k i}+v_{i}
$$

And that $Y_{i}=1$ if $Y_{i}^{*}>0$ or $Y_{i}=0$ otherwise. 
That means $\mathrm{Y}_{\mathrm{i}}$ is the dependent variable of whether the farm household adopted riverbed farming or not, $x_{1}, x_{2}, x_{3} \ldots x_{k}$ represent vector of random variables, $\beta$ represents a vector of unknown parameters and $v$ represents a random disturbance term (Nagler, 2002).

\section{Results and Discussions}

During the empirical model and variables selection, we expected the variables such as education, family size, economically active members, land holding in plains and total land holdings (acre) and crop diversity to be positive, whereas variables such as age, gender, occupation could be either positive or negative based on the context and land affected variable is expected to be negative. The empirical results showed that the coefficient of economically active members is positively significant to the riverbed farming at 0.05 level as expected, whereas family size and land affected are negatively significant to the riverbed farming among the total independent variables. The variable family size was expected to be positive whereas land affected (acre) was expected to be negative as result has shown. The coefficient of factors such as gender, education, total land holding (acre), and crop diversity showed the negative impacts on the riverbed farming though most of these variables were expected to be positive, whereas rest of the factors such as age and occupation showed the positive but not significant (Table 2).

Table 1. Variables for Probit Regression Model for factors affecting riverbed farming in Deukhuri valley

\begin{tabular}{|c|c|c|c|c|c|}
\hline S.N. & Variables & Unit & $\begin{array}{c}\text { Mean } \\
\text { (Sta. Dev.) }\end{array}$ & Range & $\begin{array}{l}\text { Expected } \\
\text { sign }\end{array}$ \\
\hline 1. & Age (age) & Number of years & $38.66(11.19)$ & $16-70$ & $+/-$ \\
\hline 2. & Gender (gender) & $\begin{array}{l}\text { Dummy; = } 1 \text { if female, } 0 \\
\text { otherwise }\end{array}$ & $0.49(0.50)$ & & $+/-$ \\
\hline 3. & Education (edu) & $\begin{array}{l}\text { Categorical, illiterate }=1, \\
\text { literate }=2, \quad \text { primary }=3, \\
\text { lower secondary }=4, \\
\text { secondary }=5, \text { higher } \\
\text { secondary }=6 \text {, bachelors } \\
=7, \text { more than bachelors } \\
=8\end{array}$ & $5.04(2.52)$ & & + \\
\hline 4. & Occupation (occu) & $\begin{array}{l}\text { Dummy; }=1 \text { if } \\
\text { Agriculture, } 0 \text { otherwise }\end{array}$ & $1.71(0.45)$ & & $+/-$ \\
\hline
\end{tabular}




\begin{tabular}{|c|c|c|c|c|c|}
\hline 5. & Family size (fam_siz) & $\begin{array}{l}\text { Number of family } \\
\text { members }\end{array}$ & $6.25(2.62)$ & $2-20$ & + \\
\hline 6. & $\begin{array}{l}\text { Economically active } \\
\text { member (econ_active) }\end{array}$ & $\begin{array}{l}\text { Number of members } \\
\text { active economically }\end{array}$ & $4.13(1.91)$ & $1-12$ & + \\
\hline 7. & $\begin{array}{ll}\text { Land } & \text { holding } \\
\text { (Plain)_Acre } & \end{array}$ & Land in acre & $0.79(0.87)$ & $\begin{array}{l}0.16- \\
8.36\end{array}$ & + \\
\hline 8. & $\begin{array}{l}\text { Total Land holding } \\
\text { (tl_land_acre) }\end{array}$ & $\begin{array}{l}\text { Total Land holding in } \\
\text { acre }(1 \text { ha }=2.47 \text { acre })\end{array}$ & $1.05(1.04)$ & $\begin{array}{l}0.16- \\
10.03\end{array}$ & + \\
\hline 9. & Land affected (acre) & Land affected by flood & $0.26(0.30)$ & $\begin{array}{l}0.2- \\
1.67\end{array}$ & - \\
\hline 10. & Crop diversity & $\begin{array}{l}\text { Number of crops } \\
\text { cultivated per household } \\
\text { in a year }\end{array}$ & $15.06(2.75)$ & $1-21$ & + \\
\hline
\end{tabular}

The most possible reasons for these results as economically active population contribute in riverbed farming as it is a labor-intensive farming which is seasonal in nature. Since all the family members in the household are not engaged in the agriculture sector the coefficient of family size maybe appeared to be significantly negative. Likewise, the land affected (acre) appeared to be significantly negative as most of households reported the land affected from flood and flood-induced riverbank erosion. Most of the population (more than $90 \%$ of the local people) are relying on agriculture for their livelihood, economy and welfare. That is why, occupation is positive though not significant that may indicate affected households most likely adopt the riverbed farming as the alternative form of agriculture. We assumed that the occupation to be either positive or negative in this study, but the results already shows that occupation in agriculture is supportive for them to adopt RbF farming. Similar study done in Malawi report family size, occupation, education, market and land holding size as important factors for adopting riverbed farming (Zidana et al. 2007). This was one of the government's strategies to promote and accelerate sustainable agriculture and economic development and food security in Malawi. In this study, the crop diversity is negative towards adoption of riverbed farming. The reason could be limited species of the cucurbits being cultivated in the riverbeds. The study carried out by USC Canada (2013) in Eastern Nepal indicated significant importance of riverbed farming in enriching crop diversity, which revealed 21 species of plants and 31 types of wildlife in the riverbed farming areas since its nearby by community forests. 
Table 2: Probit Regression Model analysis for factors affecting riverbed farming in Deukhuri valley

\begin{tabular}{|l|l|l|l|l|l|l|}
\hline \multicolumn{1}{|c|}{ Riverbedfarming } & \multicolumn{1}{c|}{ Coef. } & \multicolumn{1}{c|}{ Std. Err. } & \multicolumn{1}{c|}{$\mathrm{z}$} & \multicolumn{1}{c|}{$\mathrm{P}>|\mathrm{z}|$} & \multicolumn{2}{c|}{$[95 \%$ Conf. Interval] } \\
\hline age & .0026704 & .0157979 & 0.17 & 0.866 & -.028293 & .0336337 \\
\hline gender & -.1994556 & .3156154 & -0.63 & 0.527 & -.8180505 & .4191393 \\
\hline edu & -.0410019 & .074857 & -0.55 & 0.584 & -.187719 & .1057152 \\
\hline occu & .1325615 & .0958199 & 1.38 & 0.167 & -.0552421 & .3203651 \\
\hline fam_siz & -.2258063 & .1261595 & -1.79 & $0.073 *$ & -.4730744 & .0214617 \\
\hline econ_active & .3349531 & .1802855 & 1.86 & $0.063 *$ & -.0184 & .6883061 \\
\hline Land_holding_PlAcre & 1.431611 & .9194141 & 1.56 & 0.119 & -.3704077 & 3.233629 \\
\hline tl_land_acre & -.9214202 & .7703892 & -1.20 & 0.232 & -2.431355 & .5885148 \\
\hline Landaffected & -1.097367 & .635088 & -1.73 & $0.084 *$ & -2.342116 & .147383 \\
\hline crop_div & -.0120196 & .0569821 & -0.21 & 0.833 & -.1237025 & .0996633 \\
\hline _cons & .1097355 & 1.134616 & 0.10 & 0.923 & -2.114071 & 2.333542 \\
\hline
\end{tabular}

* significant at $\mathrm{P}=0.05$, Source: Field Survey 2016 and 2017

\section{Conclusions and Way forward}

$\mathrm{RbF}$ is gaining popularity among farmers, especially among the poor, ethnic and landless farmers as the alternative form of agriculture which is also an effective form of adaptation practice/strategy. It is specially promoted by private and civic stakeholders in Nepal. Among the variables selected in the study, economically active members in the households is positively significant to the adoption of $\mathrm{RbF}$ whereas family size and land affected in acre are negatively significant to its adoption at 0.05 significance level. This form of agriculture is important as a source of food and nutrition and also as the effective adaptation strategy and practice in degraded lands. The government (public) offices should promoted this farming in the specific regions in addition to the private and civic sectors. This study could not capture the economic aspects of the farming including the total costs incurred and the economic returns and environmental and other social benefits, which is crucial to analyze the cost-effectiveness and sustainability of this farming since mostly it is supported by the I/NGOs in the region. Furthermore, it is advisable to carry out studies on seeds and market accessibility and collective marketing systems in addition to the access to the credit and information. 


\section{References}

Alam, G. M. M., Alam, K., Mushtaq, S., Clarke, M. L. 2017. Vulnerability to climatic change in riparian char and river-bank households in Bangladesh: Implecation for policy, livelihoods and social development. Ecological Indicators. 72: 23-32. Doi: 10.1016/j.ecolind.2016.06.045

Alam, G. M. M., Alam, K., Mushtaq, S., Sarkar, M. N. I., Hossain, M. 2019. Hazards, food insecurity and human displacement in rural riverine Bangladesh: Implications for policy. International Journal of Disaster Risk Reduction. http://doi.org/10.1016/j.ijdrr.2019.101364

DDC-Dang, 2071 (V. S.). District Profile Dang, 2071 V. S., District Development Committee, Dang.

Gurung, G. B., Koirala, P., Pande, D. P., Basnet, D. B., Kafle, O. 2012. Promoting rural livelihoods through riverbed vegetable farming in the Terai region of Nepal. Journal of International Development and Cooperation. 18 (4): 113-121

Maharjan, S. K. 2017. Riverbed farming as a source of income, family nutrition and food security for landless and poor farmers in Terai Region of Nepal. Scientia Ricerca: Innovative Techniques in Agriculture. 2 (1): 316-319. ISSN: 2575-5196

Mittal, S., Mehar, M. 2015. Socio-economic factors affecting adoption of modern information and communication technology by farmers in India: Analysis using Multivariate Probit Model. The Journal of Agricultural Education and Extension, 22(2): 199-212. Doi: 10.1080/1389224X.2014.997255

MoE, 2010. National adaptation programme of actions (NAPA) to climate change, Ministry of Environment, Government of Nepal, Kathmandu, Nepal

Mor, V. B., Parmer, H. C., Patel, S. R. 2018. Riverbed farming: Means of livelihood. International Journal of Chemical Studies. 6(2): 3423-3425

Nagler, J. 2002. Interpreting probit analysis. New York University Webpage. http://www.nyu.edu/classes/nagler/quant1/probit1_post.pdf (Accessed on 27 December 2019)

Naz, F., Doneys, P., Saqib, S. E. 2018. A. 2018. Adaptation strategies to floods: A genderbased analysis of the farming-dependent char community in the Padma floodplain, Bangladesh. International Journal of Disaster Risk Reduction. 28: 519-530. Doi: 10.1016/j.ijdrr.2017.12.016 
Saqib, S., Ahmad, M. M., Paneza, S., Ali, U. 2016. Factors influencing farmers adoption of agricultural credit as a risk management strategy: The case of Pakistan. International Journal of Disaster Risk Reduction. Doi: 10.1016./j.ijdrr.2-16.03.008

SATNET Asia. 4 October 2014. Leasehold riverbed vegetable farming. Technology factsheet. SATNET Asia, CAPSA-ESCAP and European Union, Bogor, Indonesia, www.satnesasia.org

Schiller, K., Kriesemer, S., Gerster-Bentaya, M. 2013. Smallholders' adaptations to the effects of climate change: The sustainability of leasehold riverbed farming in the Terai. Conference on International Research on Food Security, Natural Resource Management and rural Development organized by the University of Hohenheim, Tropentag 2013, Stuttgart, Germany, September 17-19, 2013

Sebopetji, T. O., Belete, A. 2009. An application of probit analysis to factors affective smallscal farmers' decision to take credit: A case study of the Greater Letaba Local Municipality in South Africa. African Journal of Agricultural Research. 4 (8): 718-723. http://academicjournals.org/AJAR, ISSN 1991-637X

Sisahaniya VDC (2073 V. S.). Village Profile. Sisahaniya Village Development Committee, Dang

TECA. N.D. Bagar farming (Baluwa kheti) in river banks of Nepal. http://teca.fao.org/technology/bagar-farming-baluwa-kheti-river-banks-nepal

(Accessed in 12 December 2019)

UN-NIP, (2017). United Nations Nepal Information Platform. http://www.un.org.np (Accessed on 5 January 2018)

USC Canada. 2013. Riverbank rehahilitation to minimize the risk of landslides and flash floods in Eastern Central Nepal. A casestudy. Canadian Coalition on Climate Change \& Development. USC Canada and Parivartan Nepal. www.c4d.ca

WEPA, 2019. State of water environmental issues. Water Environment Parternship in Asia (WEPA) www.wepa-db.net (Accessed on 4 December 2019)

Zidana, A., Kaunda, E., Phiri, A., Khalil-Edriss, A., Matiya, G., Jamu, D. 2007. Factors influencing cultivation of the Lilongwe and Linthipe River Banks in Malawi: A case study of Salima district. Journal of Applied Sciences. 7 (21): 3334-3337. ISSN 18125664 